\title{
DETEKSI BAKTERI Klebsiella pneumoniae PADA SPUTUM DENGAN METODE IMUNOSITOKIMIA MENGGUNAKAN ANTI OUTER MEMBRANE PROTEIN BERAT MOLEKUL 40 KDA Klebsiella pneumoniae SEBAGAI ANTIBODI
}

\author{
Joko Susilo*, Teguh R. Sartono**, Sumarno** \\ ${ }^{*}$ PPDS Paru FK Unibraw \\ **Laboratorium Paru FK Unibraw \\ ***Laboratorium Mikrobiologi FK Unibraw
}

\begin{abstract}
Klebsiella pneumoniae (K. pneumoniae) is a normal flora in human Gastro Intestinal Tract. This strain of K.pneumoniae are implicated the gram negative bacteria that can cause pneumonia beside urinary tract infection and nosocomial infection. Until now, to identify this bacteria there are seveval methods had been used included staining and culture, Elisa, histologic and serologic that need a long time. The goal of this research is to detect $K$. pneumoniae with immunocytochemistry methode using antibody of K.pneumoniae and OMP K.pneumoniae as spesific antigen. The design of this reseach was explorative descriptive. The method content of K.pneumoniae isolation, specific antigen of OMP K.pneumoniae isolation, producing antibody anti OMP K.pneumoniae, and detection this bacteria on sputum with immunocytochemistry methode respectivelly. For diagnostic test sensitivity and specificity. Analysis has been used. The result showed that molecular weight of OMP K.pneumoniae was $40 \mathrm{kDa}$, antibody of OMP K.pneumoniae could identify the OMP K.pneumoniae as antigen and could detect K.pneumoniae on sputum by using Western Blotting and immunocytochemistry. Sensitivity and specificity of this diagnostic test was $90 \%, 95 \%$ consequently.
\end{abstract}

Key words : Klebsiella pneumoniae, Outer Membrane Protein, Immunocytochemistry

\section{PENDAHULUAN}

Klebsiella pneumoniae termasuk genus Klebsiella dalam famili Enterobacteriaceae yang merupakan penghuni normal traktus digestivus. Kuman ini dan dapat diisolasi dari tinja manusia atau hewan. Pada manusia, genus Klebsiella dapat merupakan kuman penyebab pneumonia, disamping infeksi lain diluar sistim pernapasan misalnya: infeksi saluran kemih, infeksi nosokomial (1).

Pneumonia atau infeksi saluran napas bawah masih merupakan masalah utama dalam bidang kesehatan, baik di negara sedang berkembang maupun yang sudah maju. Di RSUP Persahabatan Jakarta tahun 2000, infeksi saluran napas bawah juga merupakan penyakit utama, sedangkan di Malang pneumonia merupakan salah satu penyebab dari rawat inap utama $(2,3)$.

Beberapa survei yang dilakukan di Jakarta dan Malang ternyata dapat diketahui bahwa penyebab pneumonia utama yang diambil dari bahan sputum adalah kuman $K$. pneumoniae. Soepadi P (1997) menemukan 42,85 \% kasus pneumonia di Jakarta disebabkan oleh $K$. pneumoniae, sedangkan Jabang $M$ (1998) menemukan 36,36\% pada kasus pneumonia; Hadiarto M (1997) menemukan $44,4 \%$ pada kasus pneumonia di Jakarta dan Sartono dan Sumarno di Malang (2002) menemukan 19,4\%. $(2,3)$

Untuk mengetahui penyebab pneumonia memerlukan waktu beberapa hari sehingga pada pemberian pengobatan awal pneumonia maka diberikan antibiotika secara empiris.

Untuk mengidentifikasi kuman penyebab pneumonia dapat digunakan metode-metode: pengecatan dan kultur, Elisa,

Jurnal Kedokteran Brawijaya, Vol. XX, No.1, April 2004.

Korespondensi: Sumarno; FK Unibraw; Jl. Veteran Malang-65145; telp. (0341)580993,567192 fax (0341)564755 histologi dan serologi yang semua ini memerlukan waktu yang cukup lama. Pada penelitian ini kami mencoba mendeteksi kuman $K$. pneumoniae dengan menggunakan imunositokimia dengan dasar deteksi adanya antigen spesifik kuman $K$. pneumoniae, yang selanjutnya dilakukan tes sensitifitas dan spesifitasnya.

\section{METODE PENELITIAN}

\section{Rancangan}

Penelitian ini bertujuan untuk mengidentifikasi kuman $K$. pneumonia yang ada dalam sputum penderita yang dicurigai menderita pneumonia yang disebabkan oleh kuman tersebut. Metode yang digunakan adalah rancangan penelitian yang berupa penelitian deskriptif yang dilanjutkan dengan uji diagnostik. Sampel adalah sputum yang dikelompokkan menjadi dua golongan yaitu sputum dengan reaksi imunositokimia positif dan negatif yang kemudian dilakukan uji silang dengan kultur sputum sebagai baku emas.

\section{Tempat Penelitian}

Laboratorium Biomedik Fakultas Kedokteran Universitas Brawijaya Malang dan Bangsal dan Laboratorium Mikrobiologi Rumah Sakit Dr. Saiful Anwar Malang.

\section{Waktu Penelitian}

Jadwal penelitian mulai Mei 2002 s/d Oktober 2002 atau sampai jumlah sampel tercukupi.

\section{Sampel uji diagnostik}

Sampel diambil dari sputum penderita yang dicurigai terinfeksi kuman $K$. pneumoniae yang menjalani rawat inap di bangsal Rumah Sakit Dr. Saiful Anwar Malang. Pengambilan sampel dilakukan dengan metode pengambilan sputum yang benar yaitu :

1. Berkumur dengan air hangat 
2. Kebutuhan air cukup baik dari minum maupun lewat infus.

3. Bila diperlukan ditambahkan Gliceril guaiacolate.

4. Gerakan badan ringan.

5. Tepukan dada.

6. Cara batuk yang benar :

- posisi duduk

- inspirasi dalam

- batuk dikeluarkan.

\section{Kriteria Inklusi dan Eksklusi}

Kriteria Inklusi meliputi sputum dari penderita yang dicurigai menderita pneumonia bakteriil yang belum mendapatkan terapi antibiotika dan sputum diambil dengan cara pengambilan yang benar. Sedangkan kriteria eksklusi adalah sputum dari penderita yang dicurigai menderita pneumonia bakteriil yang sudah mendapatkan terapi antibiotika sebelumnya dan pengambilan sputum yang salah.

\section{Jumlah Sampel}

Besar sampel diperkirakan dengan memperkirakan sensitifitas dan spesifisitas yang akan diperoleh, penyimpangan sensitifitas dan spesifitas yang masih diterima. Jumlah sampel dihitung menggunakan rumus besar sampel untuk proporsi tunggal yaitu perkiraan sensitifitas uji diagnostik $80 \%$ dan spesifitas $85 \%$; penyimpangan untuk sensitifitas dan spesifisitas masing-masing adalah $10 \%$ dan interval kepercayaan yang dikehendaki $95 \%(=0,05)$; maka : (4)

$\mathrm{n} 1=\mathrm{za}^{2}(0,80 \times 0,20) / 0,10^{2}=1,962 \times 0,80 \times 0,20 / 0,01=61$

$\mathrm{n} 2=\mathrm{za}^{2}(0,85 \times 0,15) / 0,10^{2}=1,962 \times 0,85 \times 0,15 / 0,01=49$

Jadi jumlah total sampel $=61+49=110$

\section{Baku Emas}

Baku emas yang kita pakai adalah hasil pemeriksaan kultur sputum. Baku emas ini dipilih karena memang merupakan modalitas diagnostik terbaik untuk kelainan yang diteliti, dan selama ini dipakai sebagai alat diagnostik (4).

\section{Cara kerja \\ Penelitian Eksploratif \\ Metode Mendapatkan Kuman Klebsiella pneumoniae (5)}

Kuman yang digunakan dalam penelitian ini diambil dari penderita pneumonia yang disebabkan oleh kuman $K$. pneumoniae yang diisolasi laboratorium Mikrobiologi Rumah Sakit Dr. Saiful Anwar Malang dengan menggunakan kit Microbact yang mempunyai ketepatan $99 \%$. Hasil isolasi kuman K. pneumoniae dilakukan perbenihan dengan Biphasic Media (MH) Sampai terbentuk koloni kuman kira-kira 50 botol yang masingmasing mempunyai volume $250 \mathrm{ml}$.

\section{Metode Isolasi Protein dari Outer Membrane Protein Klebsiella pneumoniae (5)}

Koloni kuman $\mathrm{K}$. pneumoniae yang telah didapatkan dari perbenihan dilakukan sentrifugasi $6000 \mathrm{rpm}$ selama $1 / 2$ jam, supernatannya dibuang dan diambil pelletnya.

Pellet disuspensikan dengan PBS dan ditambahkan nOctyl-B-D-glucopyranoside (NOG) $0,5 \%$ dan selanjutnya disentrifugasi $12.000 \mathrm{rpm}$ dan diambil supernatannya. Supernatan dilakukan dialisa dan disimpan untuk penelitian selanjutnya yaitu untuk menentukan spesifikasi kuman $K$. pneumoniae dan untuk membuat antibodi.

\section{SDS-PAGE K. Pneumonia dan kuman lain (5)}

Metode ini dilakukan untuk menentukan spesifitas kuman K. pneumoniae dengan membandingkan hasil SDS-PAGE dari kuman K. pneumoniae dan kuman lain yaitu E.coli, Proteus, Shigella, Salmonella, Pseudomonas dan Vibrio cholera sehingga dapat diperoleh kesimpulan bahwa protein tersebut hanya miliknya $K$. pneumoniae.

\section{Elektroelusi (5)}

Elektoelusi ini bertujuan untuk mendapatkan protein sampel yang murni dengan memotong secara horizontal gel protein yang dimaksud. Hasil potongan tersebut dipotong lagi secara vertikal sehingga setiap potongan mengandung 3 pita protein yang sama. Potongan protein dimasukkan kedalam membran dialisis yang berisi cairan running buffer elektroforesis. Perlakuan elektroelusi protein tersebut dikerjakan secara horizontal menggunakan aliran listrik $125 \mathrm{mV}$ selama 20 menit.

Hasil elusi didialisis selama 48 jam dengan cairan yang mengandung $\mathrm{H}_{2} \mathrm{O}$ pada 24 jam pertama. Sedang PBS pH 7,4 dipakai pada 24 jam kedua, masing-masing pada suhu $4{ }^{\circ} \mathrm{C}$.

\section{Metode Isolasi Antibodi dari Kuning Telur Ayam (5)}

Isolasi antibodi dari kuning telur ayam menggunakan petunjuk dari Chung (1985). Dua butir telur pertama diambil untuk isolasi antibodi preimun, kemudian pada bawah sayap ayam yang sudah bertelur tersebut disuntikkan 30 ug antigen hasil elektroelusi melalui subkutan. Suntikan yang pertama dicampur dengan complete Freud's adjuvan. Suntikan kedua dan selanjutnya dicampur dengan incomplete Freud's adjuvan dengan selang waktu 1 minggu. Telur dipanen pada hari ke 5 sampai hari ke 17 setelah pemberian suntikan booster ke 2 . Isolasi antibodi lgY diambil dari kuning telur dengan cara memisahkan bagian putih telur dan kulit kuning telur. Kuning telur disuspensikan dengan cairan buffer A yang mengandung $10 \mathrm{mM}$ kalium fosfat dan $100 \mathrm{mM} \mathrm{NaCl} \mathrm{pH} 7$ sampai volume mencapai $30 \mathrm{ml}$. Kemudian dicampur dengan larutan prophylene ethylene glygol (PEG) $6.00030 \mathrm{ml}$ 7\%. Suspensi disentrifugasi 14.000 selama 10 menit suhu $4^{\circ} \mathrm{C}$. Supernatan diambil dan disaring dengan kasa steril. Ditambahkan PEG padat sampai konsentrasi $12 \%$ dan diaduk sampai PEG larut. Larutan disentrifugasi 14.000 g selama 10 menit pada suhu $4^{\circ} \mathrm{C}$. Pelet yang mengandung Imunoglobulin $G$ Yolk sac (IgG Y) disuspensi dengan buffer A dan dicampur dengan volume yang sama PEG $24 \%$ dalam buffer $A$. Suspensi disentrifugasi $14.000 \mathrm{~g}$ selama 10 menit suhu $4^{\circ} \mathrm{C}$. Pelet dilarutkan dengan buffer A $10 \mathrm{ml}$ kemudian dilakukan dialisa dalam bufer A semalam. Selanjutnya dilakukan sentrifugasi $12.000 \mathrm{~g}$ selama 10 menit suhu $4^{\circ} \mathrm{C}$ untuk menghilangkan kotoran. Supernatan disimpan pada suhu $-20^{\circ} \mathrm{C}$ disiapkan untuk penelitian selanjutnya.

\section{Metode Western Blotting}

Metode ini bertujuan untuk menguji apakah antibodi yang kita dapatkan dari telur ayam merupakan antibodi terhadap OMP dari Klebsiella pneumonia. Gel elektroforesis tanpa pewarnaan direndam dalam transfer buffer selama 40 menit. Membran nitroselulosa direndam dalam transfer buffer selama 40 menit. Filter tebal (2 buah) ditambah Kasa biasa (2 buah) direndam dalam transfer buffer selama 5 menit. 
Susun Sandwich terdiri dari filter tebal 2 buah, kertas saring 2 buah, Nitrocellulose membrane, gel, kertas saring 2 buah dan filter tebal 2 buah.

Transfer pada 0,3 A, 20 Volt selama 2 jam. Cuci membrane nitroselulosa dengan aquadest untuk menghilangkan gel yang melekat. Rendam dengan Ponceau $2 \%$ selama 3 menit. Cuci dengan aquadest sampai warna hilang. Blocking dengan TBS pH 7,4 dan BSA $3 \%$ selama 2 jam menggunakan shaker pada suhu ruangan. Tambahkan antibodi primer perbandingan 1: 100 overnight pada suhu $4^{\circ} \mathrm{C}$. Inkubasikan pada suhu ruangan pada shaker selama $2 \mathrm{jam}$. Cuci dengan TBS 3 kali 5 menit. Tambahkan substrat alkaline phosphatase selama 30 menit dan siap direkam.

\section{Penelitian untuk Uji diagnostik}

Prosedur Pengecatan (21)

Usapkan sputum pada obyek glass dan keringkan dalam udara. Fiksasi dengan alkohol $96 \%$. Rehidrasi dengan alkohol bertingkat $(80 \%, 70 \%, 50 \%, 30 \%)$ masing-masing 3 menit. Cuci dengan PBS pH 7,4 selama 4 menit dan diulang sampai 3 kali. Tetesi dengan BSA (Bovine Serum Albumin) dan diinkubasi 20 menit, kemudian keringkan. Tetesi sampel tersebut dengan antibodi primer ( $\lg G$ Y) dan inkubasi selama 60-120 menit pada suhu ruangan atau semalam pada suhu $4{ }^{\circ} \mathrm{C}$. Kemudian cuci dengan PBS pH 7,4 selama 2 menit sebanyak 3 kali. Tetesi dengan Antibodi sekunder Alkaline phosphatase conjugate 20 menit dan cuci dengan PBS lagi 3 kali. Tetesi dengan substrat untuk Alkaline phosphatase yaitu NBT (Nitro Blue Tetrazolium). Cuci dengan destilated $\mathrm{H}_{2} \mathrm{O}$ dan dikeringkan. Counterstain dengan Mayer Hematoxiline 5 menit. Cuci dengan air mengalir dan keringkan.

Sampel dilihat dibawah mikroskop cahaya $1.000 \mathrm{x}$, bila terdapat antigen dari kuman Klebsiella pneumoniae akan tampak warna biru keunguan, sedangkan bahan lain berwarna biru kemerahan.

\section{Tes silang sampel sputum dangan kultur}

Untuk membandingkan hasil peneriksaan imunositokimia ini, maka sputum juga dilakukan kultur untuk melihat apakah sputum yang positif mengandung kuman K.pneumoniae dengan reaksi imunositokimia akan tumbuh kuman K.pneumoniae dan sebaliknya sputum yang negatif tidak akan terjadi pertumbuhan kuman K.pneumoniae.

Pemeriksaan kultur sputum dilakukan oleh Ahli Mikrobiologi Rumah Sakit Dr. Saiful Anwar Malang yang tidak mengetahui hasil pemeriksaan imunositokimia sputum. Hasil kultur dinyatakan tumbuh kuman Klebsiella pneumonia atau tidak.

\section{Analisis data}

Setelah pengumpulan data selesai, dilakukan tabulasi hasil uji diagnostik (imunositokimia) dan hasil pemeriksaan baku emas (kultur sputum) untuk setiap sputum pasien.

Untuk mendapatkan kwalitas uji diagnostik maka dibuat kriteria positif dengan menggunakan cut off sebagai berikut:

- Positif 1: bila dari seluruh lapangan pandang hanya didapatkan sedikit bakteri.

- Positif 2: bila dari tiap lapangan pandang terdapat sedikit bakteri.

- Positif 3: bila dari tiap lapangan pandang terdapat banyak bakteri.
Selanjutnya hasil tabulasi tersebut disusun dalam tabel 2 x $2 \mathrm{sbb}$. : (4)

\begin{tabular}{|c|c|c|c|c|}
\hline \multirow{6}{*}{$\mathrm{HI}$} & & \multicolumn{2}{|c|}{ HK } & \\
\hline & & + & - & \\
\hline & + & $A$ & $B$ & $=A+B$ \\
\hline & & & & \\
\hline & - & C & $\mathrm{D}$ & $=C+D$ \\
\hline & & $A+C$ & $B+D$ & $=A+B+C+D$ \\
\hline
\end{tabular}

Keterangan:

HK: Hasil Kultur

HI: Hasil Imunositokimia

Sensitifitas:

$\mathrm{A} / \mathrm{A}+\mathrm{C} \times 100 \%=\%$

Spesifitas :

$\mathrm{D} / \mathrm{B}+\mathrm{D} \times 100 \%=\quad \%$

Nilai prediksi positif :

$\mathrm{A} / \mathrm{A}+\mathrm{B} \times 100 \%=\quad \%$

Nilai prediksi negatif :

$D / C+D \times 100 \%=\quad \%$

\section{HASIL PENELITIAN}

\section{Hasil Survei}

Survei yang dilakukan di Laboratorium Mikrobiologi Klinik RSUD Dr. Saiful Anwar Malang tahun 2002 didapatkan hasil seperti pada tabel 1 dan tabel 2 .

Tabel 1. Profil isolat bakteri yang berasal dari sputum penderita yang dirawat di RSUD Dr. Saiful Anwar Malang 2002.

\begin{tabular}{|c|l|c|c|}
\hline No. & Jenis isolat bakteri & Jumlah & $\%$ \\
\hline 1 & Klebsiella pneumoniae & 20 & 18 \\
\hline 2 & Staph. Coagulase pos. & 14 & 12,7 \\
\hline 3 & Staph. Coagulase neg. & 14 & 12,7 \\
\hline 4 & Streptococcus.sp & 11 & 9,9 \\
\hline 5 & Acinetobacter anitratus & 10 & 9 \\
\hline 6 & E. colli & 8 & 7,3 \\
\hline 7 & Candida & 7 & 6,9 \\
\hline 8 & Ps. Sketzeri & 4 & 9,6 \\
\hline 9 & Pseudomonas & 3 & 2,7 \\
\hline 10 & Lain-lain & 18 & 16,3 \\
\hline \multicolumn{2}{|c|}{ Jumlah } & 110 & 100 \\
\hline
\end{tabular}

Menurut tabel diatas $K$. pneumoniae merupakan isolat yang terbanyak 20 isolat $(18 \%)$, disusul Staphylococcus coagulase positif, Staphylococcus coagulase negatif, Strepstococcus sp dan Acinetobacter anitratus. 
Tabel 2. Hasil sensitifitas kuat dari kuman $K$. pneumoniae $(n=20)$ yang diisolasi dari sputum penderita yang dirawat di RSUD Dr. Saiful Anwar Malang 2002

\begin{tabular}{|c|l|c|c|}
\hline No & Jenis obat & Frekwensi & (\%) \\
\hline 1. & Ampicillin & 3 & 15 \\
\hline 2 & Amox-Clav.Ac. & 19 & 95 \\
\hline 3 & Cefotaxim & 20 & 100 \\
\hline 4 & Cefuroxim & 6 & 30 \\
\hline 5 & Cephalotin & 18 & 90 \\
\hline 6 & Gentamycin & 20 & 100 \\
\hline 7 & Netimicine & 20 & 100 \\
\hline 8 & Amikacine & 20 & 100 \\
\hline 9 & Ciprofloxacine & 16 & 80 \\
\hline 10 & Norfloxacine & 19 & 95 \\
\hline 11 & Tetracycline & 11 & 55 \\
\hline 12 & Cotrimoxazole & 18 & 90 \\
\hline 13 & Fosfomycine & 19 & 95 \\
\hline
\end{tabular}

Tampak bahwa kuman K. pneumoniae masih peka terhadap obat-obat: Amoxicylline-Clavulanate acide, Cefotaxime, Cefuroxime, Cephalotine, Gentamycine, Netilmicine, Amikacine, Ciprofloxacine, Norfloxacine, Cotrimoxazole dan Fosfomicine.

\section{Hasil Elektroforesis kuman K. pneumoniae dan kuman Lain}

Monitoring bobot molekul protein dari 8 galur kumankuman Enterobac-teriaceae dengan menggunakan SDS-PAGE.

Hasil elektroforesa kuman Klebsiella pneumoniae dibanding dengan kuman-kuman famili Enterobacteriaceae ditampilkan pada gambar 1 .

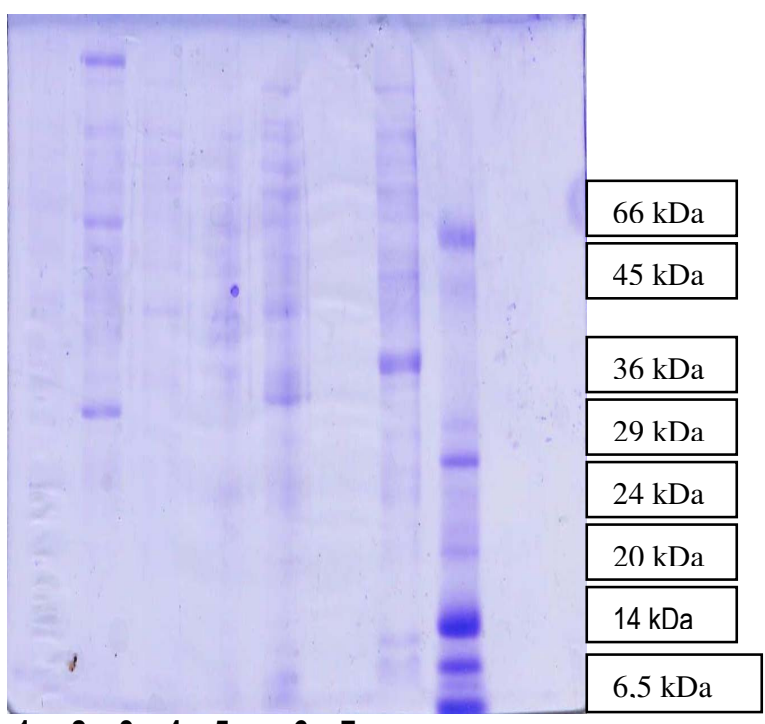

$\begin{array}{lllllll}1 & 2 & 3 & 4 & 5 & 6 & 7\end{array}$

Gambar 1. Hasil elektroforesa kuman Klebsiella pneumoniae dibandingkan dengan kumankuman dalam famili Enterobacteriaceae.

Lajur 1: Protein Proteus. Lajur 2: Protein Enterobacter. Lajur 3: Protein Staphylococcus coagulase positif. Lajur 4: Pseudomonas. Lajur 5: Protein E.colli. Lajur 6: Protein A.anitratus. Lajur 7: Protein Klebsiella pneumoniae. Lajur 8: Protein perunut menggunakan petanda albumin $66 \mathrm{kDa}$., ovalbumin $45 \mathrm{kDa}$., glyceraldehyde-3-phosphat dehydrogenase $36 \mathrm{kDa}$., carbonic anhydrase $29 \mathrm{kDa}$., trypsinogen $24 \mathrm{kDa}$., trypsin inhibitor $20 \mathrm{kDa}$., a-lactlabumin 14,2 kDa. Dan aprotinin 6,5 kDa.
Hasil immunoblotting antibodi terhadap OMP Klebsiella pneumoniae diantara kuman famili Enterobacteriaceae dapat dilihat pada gambar 2 .

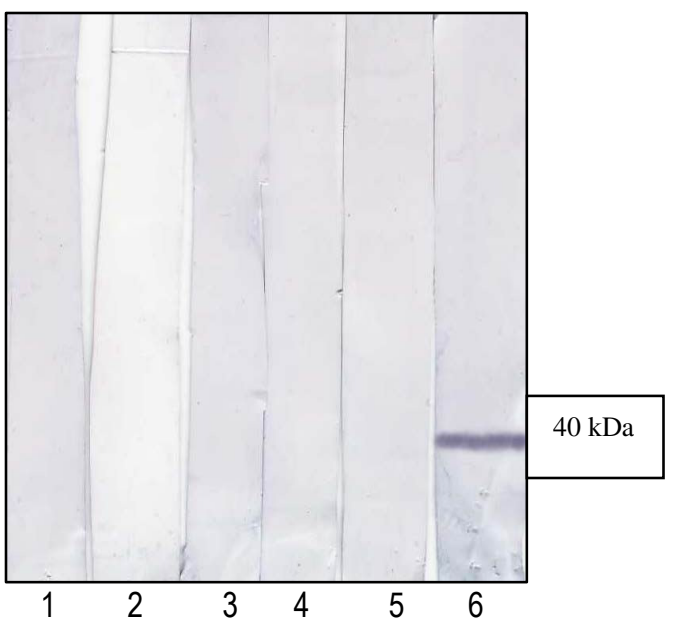

Gambar 2. Hasil imunoblotting antibodi terhadap OMP Klebsiella pneumoniae dibandingkan dengan kuman-kuman yang tergolong famili Enterobacte-riaceae.

Lajur 1: kuman Enterobacter. Lajur 2: kuman Staphylococcus coagulase positif. Lajur 3: kuman pseudomonas. Lajur 4: kuman $E$. colli. Lajur 5: kuman A.anitratus. Lajur 6: kuman Klebsiella pneumoniae.

Dari gambar tersebut terlihat bahwa yang dikenali oleh antibodi terhadap OMP K. pneumoniae adalah hanya kuman $\mathrm{K}$. pneumoniae sementara kuman-kuman yang lain tidak dikenali sehingga bisa dikatakan bahwa antibodi tersebut memang anti terhadap kuman K. pneumoniae. Kedudukan pita $40 \mathrm{kDa}$ relative dibawah oleh karena perlakuan elektroforesis waktunya lebih lama.

Hasil immunoblotting Antibodi terhadap OMP K. pneumoniae pada sputum terlihat pada Gambar 3.

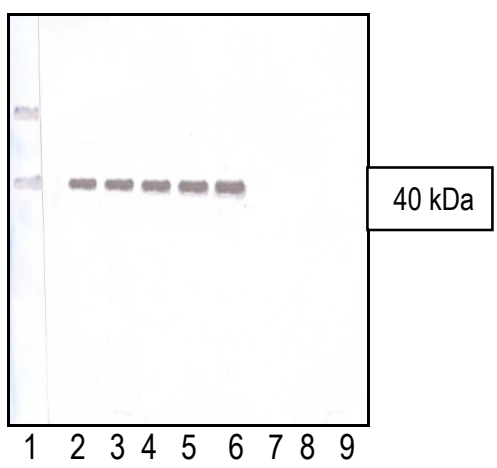

Gambar 3. Hasil immunoblotting antibodi terhadap OMP Klebsiella pneumoniae pada sputum yang diambil dari penderita pneumonia karena kuman Klebsiella pneumonia dibanding dengan kuman lainnya (konfirmasi dengan hasil kultur).

Lajur 1: Protein perunut. Lajur 2 - 6: Protein sel bakteri utuh $K$. pneumoniae dalam sputum. Lajur 7-9: protein sel bakteri non $K$. pneumoniae dalam sputum. 
Dari gambar tersebut terlihat bahwa yang dikenali oleh antibodi terhadap $K$. pneumoniae adalah pada bahan sputum yang mengandung kuman $K$. pneumoniae (sesuai hasil kultur). Sedangkan sputum yang mengandung kuman yang lainnya tidak dikenali.

Hasil Pengecatan Gram Bakteri K. pneumoniae tampak pada Gambar 4.

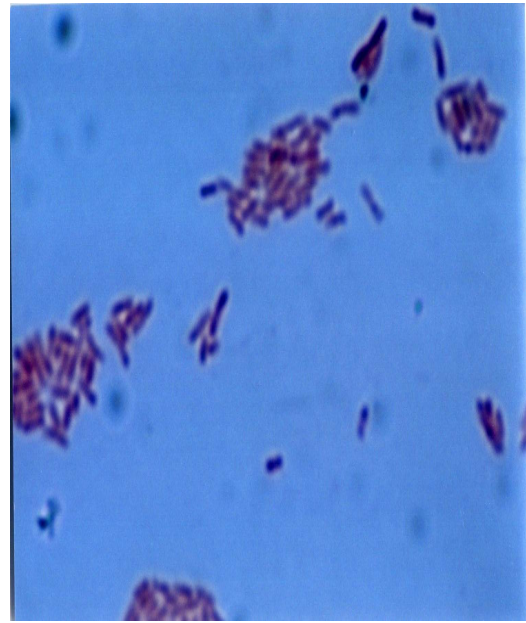

Gambar 4. Hasil pengecatan gram bakteri Klebsiella pneumoniae.

Pada pengecatan gram bakteri $K$. pneumoniae tampak kuman batang biru kemerahan.

Hasil imunositokimia antibodi terhadap OMP $K$. pneumoniae pada sputum yang mengandung kuman $K$. pneumonia dan kuman-kuman lainnya (konfirmasi dengan hasil kultur) seperti Gambar 5.

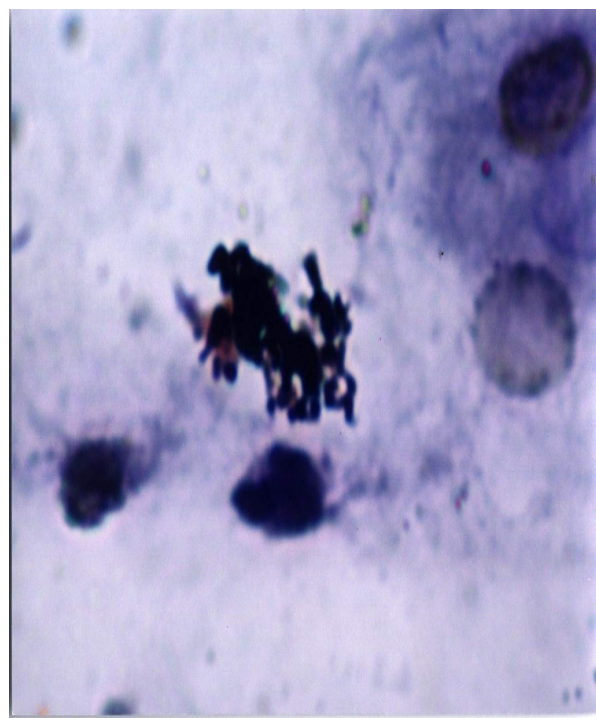

Gambar 5. Hasil imunositokimia antibodi terhadap OMP Klebsiella pneumoniae pada sputum yang mengandung kuman Klebsiella pneumonia dan kuman-kuman lainnya (konfirmasi dengan hasil kultur).
Pada sediaan sputum yang mengandung bakteri $K$. pneumoniae (sesuai dengan hasil kultur), dilakukan pengecatan imunositokimia dengan menggunakan antibodi terhadap OMP $K$. pneumoniae, tampak bentukan bakteri batang bergerombol, berwarna biru keunguan yang dikelilingi sel-sel radang.

Hasil imunositokimia antibodi terhadap OMP $K$. pneumoniae pada sputum yang mengandung kuman bukan $K$. pneumoniae (konfirmasi dengan hasil kultur) seperti Gambar 6 .

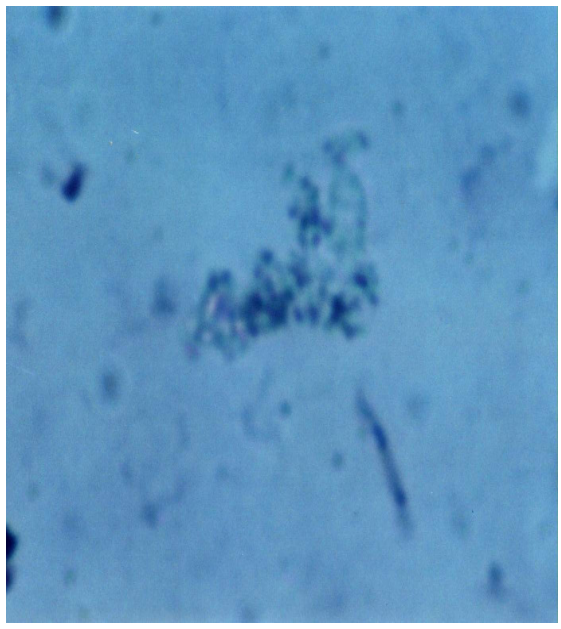

Gambar 6. Hasil imunositokimia antibodi terhadap OMP Klebsiella pneumoniae pada sputum yang mengandung kuman bukan $K$. pneumoniae (konfirmasi dengan hasil kultur).

Pada sediaan sputum yang mengandung bakteri selain $K$. pneumoniae (sesuai dengan hasil kultur), dilakukan pengecatan imunositokimia dengan menggunakan antibodi terhadap OMP K. pneumoniae, tampak bentukan bakteri batang pendek, bergerombol, berwarna biru kemerahan.

Hasil uji diagnostik antibodi anti OMP K. pneumoniae terhadap bakteri $K$. pneumoniae yang terdapat pada sputum, dengan menggunakan metode imunositokimia didapatkan sebagai berikut:

\begin{tabular}{|c|c|c|c|c|}
\hline \multicolumn{4}{c}{} & \multicolumn{3}{c|}{ HK } \\
\cline { 3 - 5 } \multicolumn{1}{c|}{} & + & - & \multicolumn{1}{c|}{} \\
\cline { 2 - 5 }$H \mathrm{HI}$ & + & 18 & 4 & $=22$ \\
\cline { 2 - 5 } & & & & \\
\cline { 2 - 5 } & - & 2 & 86 & $=88$ \\
\hline & & 20 & 90 & $=110$ \\
\hline
\end{tabular}

Keterangan:

HK: Hasil Kultur

HI: Hasil Imunositokimia

Sensitifitas :

$A / A+C \times 100 \%=18 / 18+2 \times 100 \%=90 \%$ Spesifitas:

$D / B+D \times 100 \%=86 / 86+4 \times 100 \%=95 \%$ Nilai prediksi positif :

$A / A+B \times 100 \%=18 / 18+4 \times 100 \%=81,8 \%$ Nilai prediksi negatif :

$D / C+D \times 100 \%=86 / 86+2 \times 100 \%=97,7 \%$ 


\section{PEMBAHASAN}

Dari survei yang dilakukan di Laboratorium Mikrobiologi Klinik RSUD Dr Saiful Anwar Malang tahun 2002 terhadap 110 sampel sputum, didapatkan profil isolat bakteri (Tabel I) terbanyak adalah K. pneumoniae yaitu 20 (18\%), disususul dengan bakteri Staphtlococcus coagulase positif, Staphylococcus coagulase negatif, Streptococcus dan A. anitratus. Hasil ini hampir sama dengan yang didapatkan dari Laboratorium yang sama tahun 2002 yang diambil dari semua sputum yang masuk di Laboratorium tersebut. Juga dari beberapa survei yang dilakukan di Jakarta dan Malang dapat diketahui bahwa penyebab pneumonia utama yang diambil dari sputum adalah kuman K. pneumoniae. Soepadi P (1997) menemukan 42,85\% pneumonia di Jakarta disebabkan oleh $K$. pneumoniae, di Jakarta Jabang M (1997/1998) menemukan 36,36 \%; Hadiarto M (1997) menemukan 44,4 \% dan Hadiarto M (1997/1998) menemukan 20\%; Sartono dan Sumarno di Malang 2002 menemukan $19,4 \%$.

Sedangkan hasil sensitivitas dari $K$. pneumoniae terhadap beberapa obat (Tabel 2) didapatkan sensitivitas kuat terhadap Amoxicylline-Clavulanic acide (95\%), Cefotaxim $(100 \%)$, Cephalotine $(90 \%)$, Gentamycine $(100 \%)$, Netilmycine $(100 \%)$, Amikacine $(100 \%)$, Ciprofloxacine $(80 \%)$, Norfloxacine (95\%), Cotrimoxazole (90\%) dan Fosfomycine (95\%).

Dari hasil elektroforesa Outer Membrane Protein (OMP) K. pneumoniae, menunjukkan bahwa pada OMP tersebut terdiri dari beberapa fraksi protein major dan minor. Pada penelitian ini isolasi OMP dilakukan dengan menggunakan $n$-octyl glucoside (NOG). Hal ini didasarkan pada penelitian sebelumnya bahwa OMP yang diisolasikan menggunakan NOG memberikan pola protein yang lebih banyak terutama protein major bila dibandingkan dengan OMP yang diisolasikan dengan menggunakan sarkosil.

Outer Membrane Protein K. pneumoniae yang diisolasikan menggunakan NOG didapatkan protein mayor yang mempunyai berat molekul $40 \mathrm{kDa}$.

Dari kepustakaan yang kami peroleh ternyata kapsul $K$. pneumoniae mempunyai berat molekul yang bervariasi sesuai dengan serotipenya yaitu $32 \mathrm{Kda}, 40 \mathrm{kDa}, 64 \mathrm{kDa}$ sampai 300 $\mathrm{kDa}$ (6). Disini terdapat perbedaan yang kemungkinan disebabkan adanya perbedaan lingkungan/environment yang mengakibatkan perbedaan ekspresi gene yang selanjutnya berpengaruh pada sintesa protein dan akhirnya mempengaruhi virulensi kumannya. Perbedaan bisa juga karena adanya variabilitas galur atau strain dari kuman sehingga terdapat sifat maupun protein yang berbeda.

Protein OMP K. pneumoniae yang dipilih digunakan untuk membuat antibodi dengan cara mengimunisasikan protein tersebut pada ayam. Antibodi diambil dari kuning telur ayam tersebut.

Untuk membuktikan bahwa antibodi yang kita buat adalah spesifik terhadap OMP $K$. pneumoniae, dilakukan immunoblotting baik terhadap koloni kuman maupun bahan yang diambil dari sputum.

Pada immunoblotting (Western Blotting) digunakan antibodi dari K. pneumoniae dan sebagai antigen adalah protein dari kuman-kuman famili Enterobacteriaceae sesuai dengan hasil kultur kuman. Didapatkan bahwa hanya kuman K. pneumoniae saja yang dikenali oleh antibodi tersebut, begitu juga pada immunoblotting antibodi pada sediaan sputum baik yang mengandung kuman $K$. pneumoniae maupun kuman-kuman yang lain hanya pada sputum yang mengandung kuman $K$. pneumoniae (sesuai dengan hasil kultur) yang dikenali oleh antibodi tersebut. Hal ini menunjukkan bahwa antibodi terhadap $K$. pneumoniae yang kami buat tersebut spesifik untuk kuman $K$. pneumoniae. Sejauh ini belum ada penelitian lain yang membuat antibodi terhadap $K$. pneumoniae ini, sehingga hasil ini belum bisa dibandingkan dengan hasil peneliti lain. Tetapi sebagai pedoman bahwa prosedur untuk isolasi protein maupun prosedur untuk membuat antibodi telah sesuai / mengikuti prosedur yang dilakukan oleh peneliti lain untuk kuman lain yaitu dari Chung tahun 1985 (5).

Antibodi yang didapatkan, selanjutnya digunakan untuk mendeteksi bakteri $K$. pneumoniae dalam sputum dengan prinsip reaksi antigen antibodi. Sebagai antigen adalah protein OMP dari bakteri $K$. pneumoniae yang terdapat dalam sputum tersebut. Dengan tehnik imunositokimia dimana antibodi diberi label dengan enzim Alkaline phosphatase, apabila terdapat reaksi antigen antibodi akan tampak pada dinding sel bakteri $K$. pneumonia yang berupa bentukan kuman batang dengan warna bercak-bercak biru keunguan, sementara kuman / sel-sel lain akan berwarna biru kemerahan. (7)

Dari hasil imunositokimia yang menggunakan antibodi dari anti OMP K. pneumoniae terhadap bakteri $K$. pneumoniae yang ada dalam sputum didapatkan beberapa hapusan sputum dimana imunositokimia positif tetapi kulturnya negatif dan sebaliknya hasil imunositokimia negatif tetapi hasil kultur positif. Hal ini mungkin disebabkan oleh beberapa faktor antara lain:

1. Hapusan sputum yang digunakan mungkin sudah rusak, mengingat saat pembuatan hapusan pertama sampai terakhir memerlukan waktu lebih dari 7 bulan.

2. Jumlah bakteri dalam sputum sangat sedikit sehingga tidak terdeteksi saat pemeriksaan dibawah mikroskop.

3. Sputum yang dalam kultur negatif tetapi hasil imunositokimia positif mungkin disebabkan bakteri $K$. pneumoniae dalam sputum jumlahnya sedikit, pada waktu dalam perbenihan tidak tumbuh karena didominasi oleh bakteri lain atau jamur yang dapat membunuh bakteri $K$. pneumoniae.

Dari uji diagnostik untuk mendeteksi bakteri Klebsiella pneumoniae yang ada dalam sputum dengan imunositokimia didapatkan:

- Apabila menggunakan cut off positif 1, maka sensitivitas $90 \%$, spesifitas $95 \%$, nilai prediksi positif $81,8 \%$ dan nilai prediksi negatif $97,7 \%$.

- Apabila menggunakan cut off positif 2, maka sensitivitasnya $33,3 \%$, spesifisitas $100 \%$, nilai prediksi positif $100 \%$, nilai prediksi negatif $90 \%$.

Apabila dilihat dari hasil uji diagnostik tersebut tampak bahwa deteksi bakteri $K$. pneumoniae dengan menggunakan imunositokimia cukup baik apabila menggunakan cut off positif 1 , bakteri yang terdeteksi hanya sedikit pada seluruh lapangan pandang. Tetapi bila menggunakan cut off positif 2 maka hasilnya sangat sedikit. Hal ini mungkin disebabkan sediaan hapusan yang dipakai sudah mengalami kerusakan protein, atau mungkin karena jumlah bakteri yang memang hanya sedikit. Untuk itu diperlukan penelitian yang menggunakan sputum segar 
supaya protein yang ada pada bakteri tidak rusak. Disamping itu diperlukan penelitian yang lebih spesifik untuk klinisnya misalnya penderita yang memang secara klinis khas menderita pneumonia yang disebabkan oleh K. pneumonia.

\section{KESIMPULAN DAN SARAN}

1. Dari survei yang dilakukan di Laboratorium Mikrobiologi Klinik RSUD Dr Saiful Anwar Malang tahun 2002 terhadap 110 sampel sputum, didapatkan profil isolat bakteri terbanyak adalah Klebsiella pneumoniae yaitu 20 (18\%).

2. Hasil sensitivitas dari Klebsiella pneumoniae terhadap beberapa obat didapatkan sensitivitas kuat terhadap Amoxicylline-Clavulanic acide (95\%), Cefotaxim (100\%), Cephalotine (90\%), Gentamycine (100\%), Netilmycine (100 $\%)$, Amikacine (100\%), Ciprofloxacine (80\%), Norfloxacine (95\%), Cotrimoxazole (90\%) dan Fosfomycine (95\%).

3. Outer Membrane Protein Klebsiella pneumoniae yang diisolasikan menggunakan NOG didapatkan protein mayor yang mempunyai berat molekul $40 \mathrm{kDa}$.

4. Pada immunoblotting (Western Blotting) menunjukkan bahwa antibodi terhadap $K$. pneumoniae spesifik untuk kuman $K$. pneumoniae.
5. Dari hasil imunositokimia yang menggunakan antibodi dari Anti OMP K. pneumoniae terhadap bakteri $K$. pneumoniae yang ada dalam sputum didapatkan beberapa hapusan sputum memberikan imunositokimia positif tetapi kulturnya negatif dan sebaliknya hasil imunositokimia negatif tetapi hasil kultur positif.

6. Dari uji diagnostik untuk mendeteksi bakteri $K$. pneumoniae yang ada dalam sputum dengan imunositokimia didapatkan:

- Apabila menggunakan cut off positif 1, maka sensitivitas $90 \%$, spesifitas $95 \%$, nilai prediksi positif $81,8 \%$ dan nilai prediksi negatif $97,7 \%$.

- Apabila menggunakan cut off positif 2, maka sensitivitasnya $33,3 \%$, spesifisitas $100 \%$, nilai prediksi positif $100 \%$, nilai prediksi negatif $90 \%$.

7. Perlu penelitian lebih lanjut dengan melakukan penyempurnaan terutama dalam melakukan fiksasi, metode pengecatan dan paduan laboratoris dengan kondisi klinis untuk mendapatkan uji diagnostik yang lebih tinggi.

\section{DAFTAR KEPUSTAKAAN}

1. Dzen SM. Dasar-dasar Mikrobiologi. Laboratorium Mikrobiologi Fakultas Kedokteran Universitas Brawijaya Malang. 1994.

2. Priyanti ZS. Penatalaksanaan Mutakhir Pneumonia Komuniti. Bagian Pulmonologi FKUI / RSUP Persahabatan. Jakarta; 2002.

3. Sartono dan Sumarno. Gambaran pola kuman pada pemeriksaan sputum di Rumah Sakit Umum Dr. Saiful Anwar Malang. 2002 (Unpublish).

4. Sudigdo S. Dasar-dasar Metode Penelitian Klinis. Bagian Ilmu Kesehatan Anak FKUI. Jakarta; 1995.

5. Sumarno. Karakterisasi Molekul Protein Adesi Vibrio Cholera 01 M094 V dan Protein Reseptornya pada Sel Epitel Usus Halus Tikus Putih (Wistar). Studi Patogenesis Vibrio Cholera 01 M094V. Program Pasca Sarjana Universitas Airlangga. Surabaya. 2000.

6. Kisra K, et.al. Relationships among Capsular Structure, Phagocytosis, and Mouse Virulence in Klebsiella pneumoniae. Infection and Immunity; Mar. 1995; 847-852.

7. Keith, Miller. Immunocytochemical Techniques. Theory and Practice of Histological Techniques. 5th edition. Toronto; 2002; 421-458.

8. Dzen SM. Enterobacteriaceae \& Kuman Batang Gram Negatif yang lain. Laboratorium Mikrobiologi Fakultas Kedokteran Universitas Brawijaya Malang. 1993.

9. Sydney M, Finegold MD. Enterobacteriaceae in Diagnostic Microbiology. $7^{\text {th }}$ edition. Toronto; 1986; 397-421.

10. Freeman BA. Textbook of Microbiology 22th edition. Japan; 1985; 34-35.

11. P Ustian T. The Gram Negative Cell Wall. University of Wisconsin Madison 199: 1-3.

12. Brooks GF, Botel JS, Ornston L. Medical Microbiology. Conectitut. USA. 19th edition; 1989; 15-16, $19-20$. 